\title{
Use of theophylline in the investigation of pseudothrombocytopenia induced by edetic acid (EDTA-2K)
}

\author{
O OHNUMA, Y SHIRATA, K MIYAZAWA Clinical Laboratory, Yamagata University School of \\ Medicine, Yamagata, Japan
}

SUMMARY In automated cell counting of edetic acid (EDTA-2K) anticoagulated blood, thrombocytopenia is occasionally seen which bears no relation to any underlying disease. In this study a heparin and soluble theophylline mixture was used to measure accurately platelet numbers in patients with such pseudothrombocytopenia. In four normal volunteers, a theophylline concentration of more than $7 \mathrm{mg} / \mathrm{ml}$ produced no significant difference in platelet numbers between theophylline and heparin and EDTA-2K anticoagulated bloods. When blood treated with EDTA-2K was used in seven patients with pseudothrombocytopenia, falsely low platelet counts were observed in three patients immediately after sampling; in blood treated with theophylline, white cell and platelet counts remained unchanged for up to six hours after sampling. Microscopical examination of the EDTA-2K anticoagulated blood showed massive platelet clumping, but no aggregates were seen in theophylline anticoagulated blood. It is concluded that theophylline can be useful in the investigation of pseudothrombocytopenia when an automated cell counter is used.

Peripheral blood samples anticoagulated with edetic acid (EDTA-2K) are those most commonly used for counting platelets. When automated electronic cell counters are used, falsely low platelet counts sometimes result, and these have no relation to underlying disease..$^{1-5}$ In 1973 Schreiner and Bell ${ }^{6}$ first described pseudothrombocytopenia, a condition in which platelets clumped in vitro in the presence of edetic acid. Spurious leucocytosis is also observed when automated cell counters are used. ${ }^{7}$ Onder et $a l^{8}$ reported that this is caused by the activation of an abnormal protein attached to platelets at temperatures below $37^{\circ} \mathrm{C}$ in the presence of chelating agents. The clinical importance of pseudothrombocytopenia, however, is still unknown.

We noted recently that heparin used as an anticoagulant caused platelet clumping and resulted in spuriously low platelet counts, and that blood diluted with citrate solution also caused an underestimation of platelet numbers. To circumvent this problem we successfully used a heparin and soluble theophylline mixture. We then decided to discover whether this mixture was suitable for accurate platelet counting when using automated cell counters in patients with pseudothrombocytopenia.

\section{Material and methods}

Five normal volunteers (four men and one woman aged 24 to 41 years) and seven patients with pseudothrombocytopenia were studied. Table 1 details clinical data on the patients. Each blood sample was obtained using a 21-gauge needle inserted into an antecubital vein. Four $\mathrm{ml}$ of blood were withdrawn into a $5 \mathrm{ml}$ polypropylene syringe. Two $\mathrm{ml}$ of blood were immediately transferred to a tube containing $5 \mathrm{U}$ of heparin and $\beta$-hydroxyethyltheophylline (Sigma

Table 1 Clinical details of patients

\begin{tabular}{llll}
\hline Case No & Sex & Age & Diagnosis \\
\hline 1 & M & 60 & Lung cancer \\
2 & M & 62 & Liver cirrhosis \\
3 & M & 34 & Paroxysmal dystonic choreoathetosis \\
4 & F & 68 & Hypochromic anaemia \\
5 & F & 76 & Urinary tract infection \\
6 & M & 43 & Macrocytic hyperchromic anaemia \\
7 & M & 48 & Cancer of the stomach \\
\hline
\end{tabular}


Table 2 Effects of theophylline concentration (mean (SD)) on blood in four normal subjects

\begin{tabular}{|c|c|c|c|c|c|c|}
\hline \multirow[t]{2}{*}{ Theophylline ( $\mathrm{mg} / \mathrm{ml}$ blood) } & 0 & 3 & 5 & 7 & 10 & 0 \\
\hline & Heparin & & & & & $E D T A-2 K$ \\
\hline $\begin{array}{l}\text { White cells }\left(10^{3} / \mu \mathrm{l}\right) \\
\text { Red blood cells }\left(10^{4} / \mu \mathrm{l}\right) \\
\text { Haemoglobin }(\mathrm{g} / \mathrm{dl}) \\
\text { Haematocrit }(\%) \\
\text { Platelet count }\left(10^{3} / \mu \mathrm{l}\right) \\
\text { Capillary haematocrit }(\%)\end{array}$ & $\begin{array}{c}5 \cdot 0(1 \cdot 0) \\
495(63) \\
15 \cdot 7(2 \cdot 1) \\
45 \cdot 0(5 \cdot 4) \\
121(47)^{* *} \\
45 \cdot 5(5 \cdot 7)\end{array}$ & $\begin{array}{l}5 \cdot 4(1 \cdot 0)^{*} \\
490(61) \\
15 \cdot 6(2 \cdot 1) \\
44 \cdot 7(5 \cdot 4) \\
186(57)^{* *} \\
45 \cdot 5(5 \cdot 7)\end{array}$ & $\begin{array}{l}5 \cdot 3(1 \cdot 0) \\
498(63) \\
15 \cdot 8(2 \cdot 2) \\
45 \cdot 1(5 \cdot 5) \\
208(65)^{*} \\
45 \cdot 5(5 \cdot 7)\end{array}$ & $\begin{array}{l}5 \cdot 2(1 \cdot 0) \\
488(59) \\
15 \cdot 6(2 \cdot 1) \\
44 \cdot 3(5 \cdot 3)^{*} \\
222(63) \\
45 \cdot 5(5 \cdot 7)\end{array}$ & $\begin{array}{c}5 \cdot 2(1 \cdot 0) \\
492(61) \\
15 \cdot 6(2 \cdot 2) \\
44 \cdot 2(5 \cdot 6)^{* *} \\
221(62) \\
45 \cdot 5(5 \cdot 7)\end{array}$ & $\begin{array}{l}5 \cdot 2(1 \cdot 0) \\
492(63) \\
15 \cdot 6(2 \cdot 2) \\
45 \cdot 1(5 \cdot 5) \\
224(60) \\
44 \cdot 6(5 \cdot 8)\end{array}$ \\
\hline
\end{tabular}

Chemical Company, St Louis, Missouri), and the remaining blood into a tube containing $4 \mathrm{mg}$ EDTA$2 \mathrm{~K}$. Blood cells were counted by Coulter S Plus III (Coulter Electronics Inc., Hialeah, Florida) at room temperature immediately and three hours after sampling. In one normal subject and three of seven patients blood cells were also counted six hours after sampling. In blood samples anticoagulated with EDTA-2K or theophylline, smears were obtained by the Diff 3 spinner (Coulter Electronics, Hialeah, Florida). In four normal blood samples, haematocrit measured by automated counter was compared with that of microtechnics (capillary tube method).

Data were expressed as mean \pm standard deviation (mean (SD)). Student's paired $t$ test was used for statistical comparisons. A p value of $<0.05$ was regarded as significant.

\section{Results}

Ten $\mathrm{mg}$ of theophylline were added to $1 \mathrm{ml}$ of pooled human serum to clarify the effect of theophylline on automated cell counting. Background noise was

Table 3 Serial determinations of white cells and platelet counts in pseudothrombocytopenia

\begin{tabular}{|c|c|c|c|c|c|c|}
\hline \multirow{2}{*}{$\begin{array}{l}\text { Hours } \\
\text { after } \\
\text { sampling }\end{array}$} & \multicolumn{2}{|c|}{ Immediately } & \multicolumn{2}{|l|}{3} & \multicolumn{2}{|l|}{6} \\
\hline & $E D T A$ & $T$ & $E D T A$ & $T$ & $E D T A$ & $T$ \\
\hline $\begin{array}{l}\text { White cells } \\
\text { Control } \\
\text { Patients } 1 \\
2 \\
3 \\
4 \\
5 \\
6 \\
7\end{array}$ & $\begin{array}{c}\left(10^{3} / \mu l\right) \\
4 \cdot 4 \\
6 \cdot 2 \\
4 \cdot 4 \\
9 \cdot 9 \\
4 \cdot 8 \\
6 \cdot 8 \\
4 \cdot 3 \\
3 \cdot 8\end{array}$ & $\begin{array}{l}4 \cdot 3 \\
6 \cdot 2 \\
4 \cdot 3 \\
7 \cdot 8 \\
2 \cdot 5 \\
6 \cdot 7 \\
4 \cdot 3 \\
3 \cdot 7\end{array}$ & $\begin{array}{l}4 \cdot 5 \\
9 \cdot 9 \\
7 \cdot 4 \\
9 \cdot 1 \\
4 \cdot 3 \\
7 \cdot 9 \\
6 \cdot 0 \\
4 \cdot 0\end{array}$ & $\begin{array}{l}4 \cdot 4 \\
6 \cdot 6 \\
4 \cdot 4 \\
8 \cdot 0 \\
2 \cdot 9 \\
6 \cdot 9 \\
4 \cdot 5 \\
3 \cdot 8\end{array}$ & $\begin{array}{l}4 \cdot 5 \\
9 \cdot 7 \\
7 \cdot 4 \\
8 \cdot 7\end{array}$ & $\begin{array}{l}4 \cdot 5 \\
6 \cdot 1 \\
4 \cdot 4 \\
8 \cdot 0\end{array}$ \\
\hline
\end{tabular}

\begin{tabular}{rrrrrrr} 
Platelet count $\left(10^{3} / \mu l\right):$ & & & & \\
Control & 208 & 209 & 213 & 204 & 211 & 218 \\
Patients 1 & 290 & 268 & 57 & 261 & 61 & 279 \\
2 & 95 & 172 & 40 & 173 & 43 & 170 \\
3 & 34 & 199 & 19 & 214 & 20 & 214 \\
4 & 12 & 184 & 17 & 182 & & \\
5 & 228 & 223 & 49 & 242 & & \\
6 & 253 & 240 & 163 & 248 & & \\
7 & 152 & 156 & 90 & 150 & & \\
\hline
\end{tabular}

EDTA = EDTA-2K; T = heparin and theophylline. within the permitted limit for counting white blood cells, haemoglobin, red blood cells and platelets.

Table 2 shows haematological data using blood samples anticoagulated with EDTA-2K or theophylline in four normal subjects. A theophylline concentration of more than $7 \mathrm{mg} / \mathrm{ml}$ produced no significant difference in platelet numbers between the two types of samples, but the automated haematocrit concentration was significantly lower in theophylline blood samples. A capillary haematocrit was not different, however, so we settled on a concentration of $7 \mathrm{mg} / \mathrm{ml}$ of theophylline for diagnosing pseudothrombocytopenia.

The results of serial blood cell counting are shown in table 3. In blood anticoagulated with theophylline, white cell and platelet counts remained unchanged for up to six hours after sampling. On the other hand, EDTA-2K blood examined immediately after sampling showed low platelet counts in three patients (cases 2, 3, and 4). When EDTA-2K blood was examined three hours later, white cell counts had increased in two patients (cases 1 and 2) and platelet counts had noticeably decreased in six patients (cases 1-3 and 5-7), while there was no distinct change in theophylline blood.

In EDTA-2K blood smears and in theophylline blood smears of concentrations of less than $5 \mathrm{mg} / \mathrm{ml}$, microscopical examination showed massive platelet clumping. There was no platelet aggregate in theophylline blood smears, in which $7 \mathrm{mg}$ of theophylline had been added to $1 \mathrm{ml}$ of blood. In blood smears anticoagulated with the EDTA-2K and theophylline mixture, massive platelet clumping also occurred.

\section{Discussion}

In automated electronic cell counting of blood samples anticoagulated with edetic acid, spurious thrombocytopenia and leucocytosis are occasionally observed due to in vitro platelet clumping induced by edetic acid. ${ }^{7}$ It has been stated that in vitro platelet clumping is caused by activation of an abnormal protein in the presence of edetic acid. This abnormal protein has been identified as an immunoglobulin (agglutinin). ${ }^{16}$ Onder et al concluded that pseudo- 
thrombocytopenia in chelated blood was caused by a group of agglutinins heterogeneous with respect to their physicochemical properties. The mechanism of platelet clumping may be related to the physiological function of platelet membrane ${ }^{9}$ as edetic acid has been shown to modify platelet and red cell membranes. ${ }^{11}$ We deliberately did not use a EDTA-2K and theophylline mixture in patients with pseudothrombocytopenia.

Low platelet counts, especially in the absence of signs of haemorrhage, should always arouse the suspicions of in vitro platelet clumping, and platelet numbers should then be checked by direct examination of blood smears, or by counting the blood obtained from a fingerprick, or alternatively anticoagulated blood. ${ }^{12}$ Citrate, ${ }^{12}$ acid citratedextrose ${ }^{13}$ or acid-buffering anticoagulant (ABA) ${ }^{14}$ are commonly used as alternative anticoagulants, but thiese platelet counting methods also have some defects-for example, the manual method often induces technical error, and citrate is apt to deform the blood cell shape.

The present study, using heparin and theophylline as an antiplatelet agent, showed that this mixture was immediately soluble in blood and had no effect on blood cell numbers when an automated cell counter was used. Moreover, if more than $7 \mathrm{mg}$ of theophylline were added in $1 \mathrm{ml}$ of blood, platelet counts and white cell counts did not change until six hours after blood sampling. Microscopical examinations also indicated that theophylline blood smears showed little change in blood cell morphological detail.

EDTA-2K in some patients caused a decrease in platelet counts and an increase in white cell counts. The automated cell counter may class platelet clumps as white cells because they fall within a size similar to the white cells.

With an automated cell counter, the haematocrit of theophylline blood was slightly lower than that of EDTA-2K blood, but the capillary haematocrit did not change in the range of 0 to $20 \mathrm{mg} / \mathrm{ml}$ of theophylline blood. The reduced automated haematocrit in theophylline blood may be related to the change in electric resistance of red blood cells, because automated cell counters calculate the cell volume by analysing the electric resistance of red blood cells.

When using an automated cell counter, theophylline can be useful in the investigation of pseudothrombocytopenia.

\section{References}

1 Kjeldsberg CR, Hershgold EJ. Spurious thrombocytopenia. JAMA 1974;227:628-30.

2 Rhee CY. Spurious thrombocytopenia. JAMA 1974;228:1098.

3 Rowan RM, Fraser C, Gray JH, McDonald GA. Evaluation of a semi-automated platelet-counting system. J Clin Pathol 1977;30:361-6.

4 Cimo PL. Pseudothrombocytopenia. JAMA 1974;229:766-7.

5 Walsh PN, Mills DCB, White JG. Metabolism and function of human platelet washed by albumin density gradient separation. Br J Haematol 1977;36:281-96.

6 Shreiner DP, Bell WR. Pseudothrombocytopenia: manifestation of a new type of platelet agglutinin. Blood 1973;42:541-9.

7 Solanki DL, Blackburn BC. Spurious leukocytosis and thrombocytopenia. A dual phenomenon caused by clumping of platelets in vitro. JAMA 1983;250:2514-5.

8 Onder O, Weinstein A, Hoyer LW. Pseudothrombocytopenia caused by platelet agglutinins that are reactive in blood anticoagulated with chelating agents. Blood 1980;56:177-82.

9 Isobe T, Fujita T, Kinoshita S, Terao C, Yamaguchi N. Pseudothrombocytopenia with cold-type platelet agglutinins. Japan J Med 1983;22:9-13.

10 Zucker MB, Grant RA. Nonreversible loss of platelet aggregability induced by calcium deprivation. Blood 1978;52:505-14.

11 Pinteric L, Manery JF, Chaudry IH, Madapallimattam G. The effect of EDTA, cations, and various buffers on the morphology of erythrocyte membranes: an electron-microscopic study. Blood 1975;45:709-24.

12 Veenhoven WA, van der Schans GS, Huiges W, et al. Pseudothrombocytopenia due to agglutinins. Am J Clin Pathol 1979;72:1005-8.

13 Manthorpe R, Kofod B, Wiik A, Saxtrup O, Svehag S-E. Pseudothrombocytopenia. In vitro studies on underlying mechanism. Scand J Haematol 1981;26:385-92.

14 Berning $H$, Stilbo I. Pseudothrombocytopenia and the haematology laboratory. Lancet 1982;ii:1469-70.

Requests for reprints to: Dr O Ohnuma, Department of Clinical Laboratory, Yamagata University School of Medicine, Yamagata, Japan. 